\title{
Media Dan Kritik Sosial \\ (Analisis Pemberitaan Tanjung TV Terhadap Pemda KLU Terkait Penanganan Korban Gempa 2018)
}

\author{
Ishanan $^{\mathrm{a}, 1, *}$ \\ ${ }^{a}$ Program Studi Komunikasi Penyiaran Islam, Fakultas Agama Islam Universitas Muhammadiyah Mataram,83115, \\ Indonesia

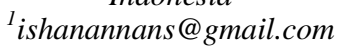

Riwayat Artikel:

Diterima: Januari 2019

Direvisi : Februari 2019

Disetujui:Maret 2019

Kata Kunci:

Media

Kritik Sosial

Analisis Wacana Kritis

Keywords:

Media

Social Critic

Critical Discourse Analysis

\begin{abstract}
Abstrak:
Ada dua persoalan yang dikaji dalam penelitian ini yaitu: (1) Apa saja kritik sosial terkait penanganan korban gempa 2018 yang dimuat di Tanjung TV? (2) Bagaimana kritik sosial terkait penanganan korban gempa 2018 dimuat di Tanjung TV? Untuk menjawab persoalan tersebut peneliti menggunakan metode kualitatif deskriptif. Dengan menggunakan pendekatan analisis wacana kritis model Teun A. van Djik, peneliti berusaha menjabarkan kritik sosial terhadap kebijakan Pemda KLU terkait penanganan korban gempa 2018. Berita yang peneliti analisis, adalah berita yang berkisar antara bulan Agustus 2018 s/d Desember 2018. Berita-berita itu juga penulis ambil secara acak. Caranya yakni dengan mengumpulkan dokumen video berita, kemudian berita dalam video itu peneliti narasikan dalam bentuk teks, dan teks itulah yanh kemudian dianalisa. Hasil dari penelitian tersebut adalah: (1) Kritik yang dimuat Tanjung TV terhap Pemda KLU terkait penanganan korban gempa sangat beragam, mulai dari kritik pendidikan, bantuan makanan, jaminan hidup, prestasi Pemda yang dinilai tak sesuai dengan keadaan masyarakat dan lainnya. (2) Tanjung TV memuat kritik sosial itu dengan membangun narasi yang saling berhubungan dari judul berita yang diangkat, sampai pada kesimpulan akhir yang ingin disampaikan dalam berita.
\end{abstract}

\begin{abstract}
:
There are two issues examined in this study, which are: (1) What are the social criticisms related to handling the victims of the 2018 earthquake published on Tanjung TV? (2) How are social criticisms related to handling the victims of the 2018 earthquake published on Tanjung TV? To answer this problem the researchers used descriptive qualitative methods. By using the critical discourse analysis approach of Teun A. van Djik's model, the researcher tries to elaborate on social criticism of the KLU Regional Government's policy related to handling the victims of the 2018 earthquake. The news that the researcher analyzes, is news that ranges from August 2018 to December 2018. News the authors also take randomly. The method is to collect news video documents, then the news in the video the researcher narrates in the form of text, and that text is then analyzed. The results of the study are: (1) Critics published by Tanjung TV on the KLU local government regarding the handling of earthquake victims are very diverse, ranging from criticisms of education, food assistance, life insurance, regional government achievements that are judged to be inconsistent with the situation of the community and others. (2) Tanjung TV contains social criticism by building interconnected narratives from the headlines raised, to the final conclusions to be conveyed in the news.
\end{abstract}




\section{Pendahuluan}

Media massa dan manusia sangat erat hubungannya. Melalui media massa, manusia bisa mendapatkan informasi yang menyangkut dirinya, orang lain, maupun lingkungannya. Setiap manusia, terutama yang hidup di zaman modern ini sangat membutuhkan media massa. Sehingga, George Gerbner dengan penuh keyakinan berkomentar bahwa media massa benar-benar telah menjadi "agama resmi" masyarakat dewasa ini. ${ }^{1}$ Dan rasanya tidak heran mengapa McQuail seperti dikutip Henry Subiakto mengatakan bahwa media adalah jendela yang memungkinkan mereka melihat apa yang terjadi di luar sana. ${ }^{2}$

Seiring dengan keberadaannya sebagai penyedia informasi, media massasemakin memegang peran yang penting dalam kehidupan manusia. Aktivitas media dalam melaporkan berbagai macam peristiwa-peristiwa sering memberi dampak yang amat signifikan bagi perkembangan keberlanjutan kehidupan manusia dalam meningkatkan dan memudahkan akses informasi. Media pun menjelma menjadi sebuah institusi sosial yang masuk ke dalam aspek-aspek kehidupan masyarakat. ${ }^{3}$

Salah satu aspek penting yang menjadi persoalan media dewasa ini adalah persoalan politik terutama yang berkaitan dengan kebijakan-kebijakan pemerintah terhadap masyarakat. Tak jarang, persoalan-persoalan itu mencakup berita tentang prestasi-prestasi elit, tapi tak jarang pula, berita-berita yang dimuat mengandung kritik. Berita dan informasi di dalamnya pun dikemas sedemikian rupa sesuai dengan ciri khas serta visi misi media terkait. Semua ini tentu tak terlepas dari fungsi-fungsi media massa dalam melakukan kegiatan jurnalistik, terlepas institusi itu milik siapa dan bernaung di bawah apa? Hal ini penting untuk menjadikan media yang bersangkutan transparan serta objektif dalam pemberitaan.

Kritik pers sejauh ini memang kadangkala dinilai sebagian pihak berlebihan, tidak proporsional, tendensius dan lain-lain. Pendapat ini mungkin saja tidak sepenuhnya keliru atau berlebihan. Sebagaimana ungkapan Goenawan Muhammad seperti dikutip Harry Susanto dari bukunya yang berjudul "Buku Putih Tempo", bahwa pers bukanlah lembaga suci. Sama dengan yang lain juga, pers bukan Tuhan. Pers pun dapat melakukan kesalahan". ${ }^{4}$ Munculnya upaya pembentukan opini kelompok tertentu dengan menggunakan pers sebagai corongnya memang tak bisa dihindari sama sekali. Hal ini tentu tidak bisa dipisahkan dari ideologi yang dianut oleh sebuah lembaga pers (media).

Ideologi sebuah lembaga pers akan senantiasa mempengaruhi corak isi pemberitaan yang dibuat. Tetapi, bagaimanapun, kritik pers senantiasa mewakili persoalan yang muncul dan dirasakan publik secara luas. Maka, di sini tidak hanya diperlukan kecerdasan insan pers dalam melancarkan kritik, tetapi juga diperlukan kecerdasan pihak pemerintah dan penyelenggara negara untuk melakukan refleksi dan introspeksi agar kritik yang datang dapat dipilah. Lebih dari itu, kritik, seburuk apapun rupanya, mestilah memiliki nilai informasi.

Dalam konteks Kabupaten Lombok Utara, ada sebuah media massa, yakni Tanjung TV yang aktif melakukan siaran pemberitaan secara streaming dengan menggunakan media sosial Facebook. Melalui facebook inilah Tanjung TV aktif menyajikan dan memberikan informasi kepada segenap masyarakat Lombok Utara seputar peristiwa-peristiwa yang terjadi di Kabupaten Lombok Utara. Terutama, ketika Tanjung TV menemukan momentum dengan banyak memuat berita yang berkaitan dengan peristiwa gempa Lombok Utara, dan penanganan Pemda KLU terhadap korban gempa tahun 2018. Konten-konten pemberitaannya pun mampu menyedot banyak viewer.

\footnotetext{
'Yudi Latif," Media Massa Dan Pemiskinan Imajinasi Sosial" dalam Idi Subandi Ibrahim, Kritik Budaya Komunikasi (Yogyakarta:Jalasutra 2011), h. 86

${ }^{2}$ Mc Quail dalam Henri Subiakto, Komunikasi Politik, Media dan Demokrasi, (Jakarta: Prenada Media Group, 2012), h. 106

${ }^{3}$ Alo Liliweri, Komunikasi: Serba Ada Serba Makna, (Jakarta : Kencana, 2011), h. 877

${ }^{4}$ Eko Herry Susanto, "Media Relations dan Transparansi Informasi" dalam Deddy Mulyana (Ed), Ilmu Komunikasi Sekarang dan Tantangan Masa Depan (Jakarta: Kencana. 2011), h. 333.
} 
Dalam konten pemberitaanya, Tanjung TV banyak menyorot kebijakan-kebijakan Pemda KLU terkait penanganan mereka terhadap para korban gempa yang terjadi pada tahun 2018. Gempa ini mengakibatkan lebih banyak korban jiwa dan kerusakan. Tercatat sekitar 564 orang tewas dan lebih dari 1.548 orang luka-luka. Tidak hanya menimbulkan korban, sebanyak 67.875 rumah rusak yang membuat 352.793 orang harus mengungsi dan sebanyak 1.194 sekolah rusak. Selain itu, banyak fasilitas masyarakat seperti rumah sakit dan tempat peribadatan juga rusak. Tercatat sebanyak 321 fasiitas kesehatan rusak dan tempat peribadatan sebanyak 630 masjid, 461 mushola, 1 gereja, 1 vihara dan 50 pura rusak. $^{5}$

Sehingga, berdasarkan pengamatan sementara inilah peneliti ingin mengetahui lebih dalam tentang Tanjung TV dalammemainkan perannya sebagai agen kontrol sosial (agent of socialcontrol) dalam menyikapi persoalan-persoalan yang ada di Lombok Utara, terutama dalam hal bagaimana isu-isu kritik dikemas dan dagambarkan dalam berita Tanjung TV.

Adapun rumusan masalah pada penelitian ini adalah : 1) Apa saja kritik sosial terkait penanganan korban gempa 2018 yang dimuat di Tanjung TV? 2) Bagaimana kritik sosial terkait penanganan korban gempa 2018 dimuat di Tanjung TV?

\section{Tinjauan Pustaka}

\section{A. Pengertian Pers}

Pers berasal dari bahasa Belanda yang berarti menekan atau mengepres. ${ }^{6}$ Kata "pers" merupakan padanan dari kata "press" dalam bahasa Inggris yang juga berarti "menekan atau mengepres". Jadi secara harfiah kata pers atau press mengacu pada pengertian komunikasi yang dilakukan dengan perantaraan barang cetak. Tetapi sekarang kata pers ini digunakan untuk merujuk semua kegiatan jurnalistik, terutama kegiatan yang berhubungan dengan menghimpun berita, baik oleh wartawan media elektronik maupun oleh wartawan media cetak.

Berdasarkan uraian diatas, ada dua pengertian tentang pers, yaitu pers dalam arti sempit dan dalam arti luas. Dalam arti sempit yaitu menyangkut kegiatan komunikasi yang hanya dilakukan dengan perantaraan barang cetakan. Sedangkan pers dalam arti kata luas adalah yang dilakukan dengan media cetak maupun elektronik.

\section{B. Pengertian Berita dan Nilai Berita}

Banyak definisi berita atau news yang dapat diketahui dari berbagai macam literatur. Dikalangan wartawan terkenal juga definisi yang meskipun "antik", masih juga ditemui dalam literature jurnalistik. Definisi tersebut adalah ciptaan Lord Northcliffe dari Inggris, yang berbunyi:

"If a dog bites a man it is not news, but if a man bites a dog it is news".

Dalam bukunya, Reporting, Prof. Mitchel V. Charn mendefinisiskan berita sebagai berikut:

"News is the timely refort of fact or opinion of either interest or imfortence, or both, to a considerable number of people" (berita adalah laporan tercepat mengenai fakta atau opini yang mengandung hal yang menarik minat atau penting, atau kedua-duanya, bagi sejumlah penduduk).Dengan demikian dapat disimpulkan bahwa "berita adalah suatu fakta atau ide atau opini aktual yang menarik dan akurat serta dianggap penting bagi sejumlah besar pembaca, pendengar maupun penonton. ${ }^{8}$

\footnotetext{
${ }^{5}$ Ini Data Lengkap Kerusakan Gempa Lombok Versi BNPB, https://bisnis.tempo.co/read/1125319/ini-data-lengkap-kerusakan-gempalombok-versi-bnpb diakses pada tanggal 10Maret 2019 pukul 22:18.

${ }^{6}$ Hikmat K. dan Purnama K., Jurnalistik Teori \& Praktik, (Ed), (Bandung: PT Remaja Rosdakarya 2009), h. 17.

${ }^{7}$ Lihat, Onong, Nuansa-nuansa, h. 67

${ }^{8}$ Deddy Iskandar Muda, Jurnalistik Televisi Menjadi Reporter Profesional, (Bandung: Remaja Rosda Karya, 2005 ), h. 21.
} 
Dari pengertian di atas, ada empat unsur yang harus dipenuhi oleh sebuah peristiwa, sehingga layak menjadi sebuah berita. Unsur-unsur tersebut adalah:

\section{1) Unsur aktual}

Mengandung unsur terkini, terbaru, terhangat, baru saja atau sedang terjadi.

\section{2) Unsur Faktual}

Dalam unsur faktual, kejadian benar-benar merupakan suatu kenyataan, bukan suatu rekayasa, khayalan atau karangan. Fakta dalam sebuah berita muncul dan diperoleh dari sebuah kejadian nyata, pendapat ataupun pernyataan.

\section{3) Unsur Penting ${ }^{4}$}

Ada dua hal dalam berita dinilai penting. Pertama, tokoh yang terlibat dalam pemberitaan adalah tokoh penting atau memiliki kapasitas yang telah diakui oleh masyarakat.Kedua, materi berita menyangkut kepentingan orang banyak dan mempengaruhi kondisi masyarakat.

\section{4) Unsur Menarik}

Menimbulkan rasa ingin tahu, dan ketertarikan dari masyarakat untuk menyimak isi berita tersebut. Peristiwa yang menarik dan diminati oleh masyarakat biasanya bersifat menghibur, aneh, memiliki unsur kedekatan, mengandung nilai kemanusiaan, mengandung unsur seks, kriminalitas dan konflik.

\section{5) Nilai Berita (news value). ${ }^{9}$}

Setiap berita yang ada di hapadan seorang wartawan mempunyai kadar layak berita atau biasa disebut "news value" (nilai berita). Artinya tidak semua fakta dan peristiwa di lapangan diangkat menjadi berita. Yang artinya dari sekian banyak fakta yang terjadi hanya segelintir saja yang dijadikan sebagai berita. Sehingga untuk menyatakan bahwa berita-berita yang dimuat selama ini adalah cerminan dari realitas yang sesungguhnya amat sulit.10Setiap berita yang ada di hapadan seorang wartawan mempunyai kadar layak berita yang berbeda, tergantung seberapa banyak dari syarat-syarat berikut ini yang bisa di penuhi:

1) Arti penting, yaitu kejadian yang mempunyai kemungkinan memengaruhi kehidupan orang banyak.

2) Besarnya sesuatu atau kuantitas, yaitu, kejadian yang menyangkut angka-angka yang berarti bagi kehidupan orang banyak, atau kejadian yang dapat mempunyai akibat yang dapat dijumlahkan bentuk angka yang menarik bagi pembaca.

3) Tepat waktu, yaitu yang menyangkut hal hal yang baru saja terjadi atau baru saja ditemukan.

4) Kedekatan, yaitu kejadian dekat dengan pembaca, baik dekat secara geografis maupun dekat secara emosional.

5) Ketenaran, yaitu kejadian yang menyangkut tokoh atau hal - hal yang terkenal atau dikenal oleh pembaca (public figure).

6) Segi manusiawi (human interest), yaitu kejadian yang menyentuh perasaan pembaca (mengharukan), atau kejadian yang menyangkut orang biasa dan situasi luar biasa, atau orang besar (terkenal) dalam situasi biasa.

7) Objektif: berdasarkan fakta, tidak memihak.

\footnotetext{
${ }^{9}$ Septiawan Santana K., Jurnalisme Kontemporer, (Yayasan Obor Indonesia: Jakarta, 2005), h. 17.

${ }^{10}$ Mursito, Realitas Media. (Surakarta: SmartMedia 2012), h. 111
} 
8) Aktual: terbaru, belum "basi".

9) Jarak: familiaritas, kedekatan (geografis, kultural, psikologis).

\section{Kritik Sosial}

Kritik sosial adalah salah satu bentuk komunikasi dalam masyarakat yang bertujuan atau berfungsi sebagai kontrol terhadap jalannya suatu sistem sosial atau proses bermasyarakat. Menurut Marbun, kritik sosial merupakan frase yang terdiri dari dua kata yaitu kritik dan sosial.Kritik sosial terdiri dari dua istilah yakni dari kata kritik dan sosial. Kritik, dalam Kamus Besar Bahasa Indonesia dijelaskan bahwa kritik berarti kecaman atau tanggapan, kadang-kadang disertai uraian dan pertimbangan baik buruk suatu hasil karya, pendapat dan sebagainya. Sedangkan sosial memiliki arti berteman, bersama, berserikat, bermaksud untuk mengerti kejadian-kejadian dalam masyarakat yaitu persekutuan manusia, untuk dapat berusaha mendatangkan perbaikan dalam kehidupan bersama. ${ }^{11}$

\section{Media sebagai Kontrol Sosial}

Sejumlah teorisi, dalam mengupas kekuatan komunikasi massa, juga mengakui peran komunikasi massa (media massa) sebagai kontrol sosial dalam pemeliharaan tertib masyarakat.12Dalam era listrik (Electric Age), yang dimulai sejak ditemukannya telegram, dunia sudah disatukan jaringan raksasa kabel listrik. Semenjak manusia menemukan sarana komunikasi baru, tidak hanya menciptakan alat baru komunikasi massa, namun juga mengubah esensi dari komunikasi massa itu sendiri. Ini kontras dengan dengan teori libertarian yang berkeyakinan bahwa pers atau media adalah kekuatan pembebas manusia dari tirani, kesewenang-wenangan dan kebodohan.13

Kontrol sosial oleh media massa begitu ekstensif dan efektif, sehingga sebagian pengamat menganggap kekuatan media massa memang di situ. Yakni kemampuannya dalam rekayasa kesadaran, dan ini dinyatakan sebagai kekuatan terpenting media, yang bisa dimanfaatkan untuk tujuan apaun. Media juga dapat mengubah bentuk kontrol sosial. Media dapat menghaluskan paksaan sehingga tampak sebagai bujukan. ${ }^{14}$

\section{E. Pendekatan dengan Analisis Wacana}

Istilah analisis wacana adalah istilah umum yang dipakai dalam banyak disiplin ilmu dan dengan berbagai macam pengertian. Dalam berbagai definisi, kita akan tetap menemukan bahwa analisis wacana adalah ilmu yang berhubungan dengan studi mengenai ilmu bahasa. ${ }^{15}$ Di dalam media massa, analisis wacana berfungsi sebagai pisau analisis isi media. Di mana wacana bukan hanya mengetahui bagaimana isi teks berita, tetapi bagaimana pesan atau teks komunikasi itu disampaikan. Lewat kata, frasa, kalimat, metafora macam apa suatu berita disampaikan. ${ }^{16}$

Analisis ini bekerja menggali praktek-praktek bahasa dibalik teks untuk menemukan posisi ideologis dari narasi dan menghubungkannya dengan struktur yang lebih luas. Dengan demikian analisis wacana merupakan salah satu model analisa kritis yang memperkaya pandangan khalayak bahwa ada keterkaitan antara produk media, ekonomi dan politik. Keterkaitan ini dapat dimunculkan pada saat analisis wacana bergerak menuju pertanyaan bagaimana bahasa bekerja dalam sebuah konteks dan mengapa bahasa digunakan dalam sebuah konteks dan bukan untuk konteks yang lain.

\footnotetext{
${ }^{11}$ http://www.referensimakalah.com/2012/04/Kritik-Sosial-Pengertian-dan-LatarBelakang.html. Diakses pada tanggal 18 April 2018, pukul 20. 00 WIB.

${ }^{12}$ Lihat, William L. Rivers, Media Massa \& Masyarakat, (Jakarta: Kencana, 2008), h, 36.

${ }^{13}$ Ibid, h. 38.

${ }^{14} \mathrm{Ibid}$, h. 39

${ }^{15}$ Eriyanto, Analisis wacana ; Pengantar Analisis Teks Media, (Yogyakarta,LkiS 2009), h. 4

${ }^{16}$ Frasa dalam kamus ilmiah popular berarti "kelompok kata", sedangkan metafora adalah majas (gaya bahasa) yang memperbandingkan suatu benda dengan benda lain yang mempunyai kesamaan sifat. Lihat Tim Prim, Kamus Ilmiah...h, 307.
} 


\section{F. Metode Penelitian}

Istilah penelitian kualitatif adalah jenis penelitian yang temuan-temuannya tidak diperoleh melalui prosedur statistik atau bentuk hitungan lainnya. ${ }^{17}$ Dari definisi singkat ini bisa menjelaskan penelitian ini merupakan penelitian kualitatif deskriptif dan menggunakan pendekatan analisis wacana sebagai pisau analisis di dalam memahami isi berita yang diteliti. Dengan menggunakan jenis penelitian ini, peneliti juga akan lebih leluasa dalam mengembangkan penelitian yakni media komunitas dan kritik sosial yang menjadi permasalahan di kawasan yang diteliti. Selain itu diharapkan dengan menggunakan metode penelitian ini, peneliti bisa mendapatkan deskripsi yang jelas tentang data serta informasi yang dibutuhkan agar tetap sesuai dengan fakta yang ada, dan bukan rekaan semata.

\section{1) Teknik Pengumpulan Data}

a) Metode Wawancara

Wawancara adalah salah satu cara untuk mengumpulkan informasi yang utama dalam kajian pengamatan. Ia dilakukan dengan Tanya jawab lisan dan jawaban disimpan secara tertulis, melalui rekaman kaset, video, atau media elektronik lainnya ${ }^{18}$ Peneliti sendiri menggunakan wawancara jenis semi terstruktur. Dengan tujuan untuk menemukan permasalahan secara lebih terbuka. Dalam penelitian ini peneliti akan mewawancarai orang yang dinilai kompeten dalam memberikan informasi terkait data-data yang dibutuhkan Yakni; Sahnan selaku Pendiri Tanjung TV

\section{b) Metode Dokumentasi}

Seperti yang diungkapkan oleh Suharsini Arikunto, bahwa metode dokumentasi adalah metode mencari data mengenai hal-hal yang variabelnya berupa catatan, transkrip, buku, surat kabar, majalah, prasasti, notulen, rapat, dan lain sebagainya. Berdasarkan penjelasan di atas teknik pengumpulan data yang digunakan dalam penelitian ini adalah dengan mengumpulkan dokumendokumen video terkait dengan Kebijakan Pemda KLU mengenai penanganan terhadap korban gempa 2018 yang di muat di Tanjung TV.

\section{2) Teknik Analisis Data}

Analisis data adalah proses mengatur urutan data ke dalam bentuk pola, kategori, dan satuan urutan dasar. Sehingga bisa disimpulkan bahwa analisis data dilakukan dengan mengumpulkan data yang didapatkan kemudian dianalisis dengan menggunakan metode deskriptif kualitatif yaitu setelah data-data tersusun lalu disusun dan dikelompokkan dengan menggunakan kata-kata sedemikian rupa untuk menggambarkan jawaban dari permasalahan yang telah dirumuskan sebelumnya. Adapun teknik analisis data yang digunakan dalam penelitian ini adalah dengan menggunakan analisis wacana kritis, khusunya analisis wacana model Teun A. van Dijk. menganalisis arsip video yang ada dalam berita Tanjung TV, yang kemudian penulis narasikan menjadi teks, dan teks itulah yang kemudian dianalisis dengan Struktur Teks Analisis Wacana model Teun A. van Djik.

Di dalam mediamassa, analisis wacana berfungsi sebagai pisau analisis isi media. Di mana wacana bukan hanya mengetahui bagaimana isi teks berita, tetapi bagaimana pesanatau teks komunikasi itu disampaikan. Lewat kata, frasa, kalimat, metafora macam apa suatu berita disampaikan. ${ }^{19}$

Karena bahasa merupakan aspek sentral dalam dalam menggambarkan suatu subjek, dan lewat bahasa pula ideologi terserap.Hal inilah yang dipelajari dalam analisis wacana. ${ }^{20}$

\footnotetext{
${ }^{17}$ Anselm Straus \& Juliet Corbin, Dasar-dasar Penelitian Kualitatif, (Yogyakarta: Pustaka Pelajar, 2013 ), h. 4.

${ }^{18}$ Ibid, h. 56.

${ }^{19}$ Frasa dalam kamus ilmiah popular berarti "kelompok kata", sedangkan metafora adalah majas (gaya bahasa) yang memperbandingkan suatu benda dengan benda lain yang mempunyai kesamaan sifat. Lihat Tim Prim, Kamus Ilmiah., h. 307.

${ }^{20}$ Eriyanto, Analisis Wacana, h. 337-341.
} 
Analisis ini bekerja menggali praktek-praktek bahasa dibalik teks untuk menemukan posisi ideologis dari narasi dan menghubungkannya dengan struktur yang lebih luas. Keterkaitan ini dapat dimunculkan pada saat analisis wacana bergerak menuju pertanyaan bagaimana bahasa bekerja dalam sebuah konteks dan mengapa bahasa digunakan dalam sebuah konteks dan bukan untuk konteks yang lain.

\section{Hasil Penelitian}

\section{A. Kritik Sosial dalam Pemberitaan Tanjung TV 2018}

Jika dilihat dari pemberitaan terkait kritik sosial pada Tanjung TV, dalam beberapa edisi, dapat ditemukan berita-berita yang mengandung muatan kritis. Kritik-kritik itupun beragam. Ada yang ditujukan kepada pemerintah terkait dengan kesehatan, kebutuhan sembako, pekerjaan, dan hunian pasca gempa, pelayanan public, transparansi anggaran, dan lain sebagainya.

Kritik-kritik yang dimuat, dikemas serta didukung oleh data-data yang memperkuat kritik yang ingin disampaikan. Baik itu dengan cara menyertakan komentar-komentar dari narasumbernarasumber yang mendukung kritik pada topik tertentu, atau dengan menyertakan data-data tertentu, sehingga apa yang dipaparkan dalam berita, adalah benar-benar terjadi dan merugikan khalayak.

Selain itu, untuk mendukung kritik-kritik pada topik tertentu yang ingin disampaikan dalam beberapa berita Tanjung TV, wartawan menyusun bagian-bagian berita dengan urutan tertentu. Ada tekanan mana yang didahulukan, dan bagian mana yang dibuang, sebagai strategi untuk menyembunyikan informasi penting. ${ }^{21}$

Di antara berita-berita yang mengandung kritik sosial dari beberapa edisi pada Tanjung TV di antaranya berita yang terbit pada edisi 20 Agustus 2018 dengan judul "Anak-anak Pengungsi Mulai Menderita Sakit". Pada edisi ini, kontrol sosial yang ingin disampaikan adalah harapan kepada pemerintah agar melakukan droping air bersih di wilayah pengungsian mereka yang memang sumber air yang digunakan sehari-hari, bermasalah dari sisi kesehatan. Hal ini dapat dilihat dari isi berita yang menyatakan;

Dengan menampilkan komentar warga tersebut, wartawan Tanjung TV membuat strategi pemberitaan, bahwa bagian mana saja yang ingin ditonjolkan atau ditekankan dalam berita. Apakah mengenai anak-anak yang banyak mengidap penyakit diare dan ispa, atau pada penyebab anak-anak bisa mengalami diare dan ispa, yakni kurangnya sarana air bersih ke pengungsian mereka.

Dalam edisi 1 September 2018 misalnya, judul yang ditampilkan pada tampilan utama adalah "Warga Korban Gempa Pulang ke Rumah Masing-masing. Namun, pada bagian Angel, terlebih dahulu wartawan Tanjung TV memperkuat apa yang ingin ditampilkan dalam berita ini dengan keterangan "Korban Gempa Butuh Pekerjaan Kepastian Jaminan Hidup". Edisi ini secara umum memuat tentang harapan serta kritik terhadap pemerintah terkait dengan permaslahan yang mereka hadapi pasca pulang dari pengungsian, seperti makanan yang menipis dan harta benda mereka yang habis tertindih reruntihan bangunan karena gempa. Selain itu, muatan kritik yang ditampilkan adalah, terkait tidak transparannya penyaluran bantuan oleh pemerintah, padahal selama ini, stok bantuan yang ada di BPBD begitu melimpah. Hal ini bisa dilihat dari komentar yang ditampilkan oleh wartawan Tanjung TV:

"Terkait dengan anggaran, selama itu untuk kepentingan masyrakat banyak, berapapun besar anggaran yang ada di Kabupaten Lombok Utara itu APBD, kita serahkan sepenuhnya kepada masyarakat yang saat ini sedang membutuhkan itu. tinggal kita sekarang data, apa apa yang

\footnotetext{
${ }^{21}$ Eriyanto, Analisis Wacana... h. 234
} 
menjadi skala prioritas kebutuhan masyarakat itu sesuai dengan kebutuhannya itu, sehingga bisa kita anggarkan lewat anggaran anggaran daerah itu.". 22

Dalam edisi 6 September 2018 ini, judul yang diangkat "PEMDA Dinilai Lamban Menangani Korban Gempa (Banyakan rapat Pemda KLU Dinilai Lamban Menangani Korban Gempa". Pada edisi ini, berita diawali lead yang mengatakan bahwa, akibat gempa yang melanda Kabupaten Lombok Utara 1 (satu) bulan terakhir, membuat berbagai persoalan baru, baik di sektor pemerintahan, dan berbagai layanan publik lainnya.

Selanjutnya, untuk memperkuat substansi kritik, wartawan Tanjung TV menampilkan komentar dari salah seorang tokoh masyarakat, yang merupakan mantan Ketua Komisi I DPRD KLU, Jasman Hadi yang mengatakan:

"Sangat nyata, terutama sekali bagaimana menangani persoalan dunia pendidikan, karena sudah terlalu lama anak-anak kita tidak menerima pendisikan. Maka dari itu, sekolah-sekolah yang hanya tidak dijanjikan tetapi, butuh aksi yang nyata. Kemudahan fasilitas kesehatan, infrastruktur pemerintahan, pokonya pada prinsipnya adalah pusat-pusat pelayanan publik ini segera dilakukan oleh pemerintah dan jangan menunggu waktu lama. Persoalan dana APBD yang tersedia itu, saya pikir bisa dilakukan. Lakukan segera tindakan dalam kondisi emergency, segera dilakukan perubahan anggaran dalam waktu dekat. Jangan menunggu jadwal lagi. Harus segera, Pemerintah Daerah bersama Bupati lakukan itu. Lakukan pembiayaan dengan Dana di $A P B D$ itu, untuk menyelesaikan infrastruktur, perbaikan pasca bencana ini, lalu setelah itu, ketika kita kekurangan kita minta, jngan mau disuapin dulu"

Secara umum berita-berita di atas mengandung kritik yang beragam. Kritik-kritik tersebut ada yang langsung disimpulkan sendiri oleh wartawan Tanjung TV, dan ada juga dengan cara mengutip komentar dari narasumber atau komentator yang bernada dukungan terhadap kritik yang ingin disampaikan, sehingga pesan kritis dalam berita betul-betul mengena dan sampai kepada objek dari pesan tersebut. Berikut tabel terkait Berita dengan muatan kritik sosial yang dimuat Tanjung TV dari beberara edisi, yang peneliti ambil secara acak dari bulan Agustus 2018 s/d November 2018 di antaranya sebagai berikut:

\begin{tabular}{|c|c|c|c|}
\hline No & Edisi & Judul Berita & Kritik yang disampaikan \\
\hline 1 & 20 Agustus 2018 & $\begin{array}{l}\text { Anak-anak pengungsi mulai } \\
\text { menderita sakit }\end{array}$ & $\begin{array}{l}\text { Pengungsi Butuh Perhatian } \\
\text { Pemerintah terkait Kebutuhan } \\
\text { Air bersih dan fasilitas kesehatan }\end{array}$ \\
\hline 2 & 1 September 2018 & $\begin{array}{l}\text { Korban Gempa Butuh Pekerjaan } \\
\text { dan Kepastian Jaminan Hidup }\end{array}$ & $\begin{array}{l}\text { Masyarakat butuh kepekaan } \\
\text { pemerintah terkait jaminan hidup } \\
\text { pengungsi pasca kembali ke } \\
\text { rumah masing-masing, serta } \\
\text { transparan terhadap bantuan } \\
\text { yang selama ini diberikan } \\
\text { donator }\end{array}$ \\
\hline 3 & 6 September 2018 & $\begin{array}{l}\text { Banyakan Rapat Pemda KLU } \\
\text { dinilai Lamban Menangani Korban } \\
\text { Gempa }\end{array}$ & $\begin{array}{l}\text { Kritik pada pemda yang tidak } \\
\text { berani mengambil tindakan } \\
\text { penting terkait pendidikan, } \\
\text { pelayanan public serta terlalu } \\
\text { banyak rapat tapi nol aksi. }\end{array}$ \\
\hline 4 & 27 September 2018 & $\begin{array}{lccr}\text { Kantor Bupati } & \text { KLU } & \text { Didemo } \\
\text { Korban Gempa } & \text { Terkait } & \text { dengan } \\
\text { Pencairan Dana } & & \\
\end{array}$ & $\begin{array}{l}\text { Kritik pada Pemda yang bagi } \\
\text { masyarakat, Pemda hanya sibuk } \\
\text { berjanji tanpa realisasi }\end{array}$ \\
\hline 5 & 2 Oktober 2018 & $\begin{array}{l}\text { Pendemo kantor Bupati kemarin } \\
\text { Kecewa dengan data mentah yang } \\
\text { diberikan }\end{array}$ & $\begin{array}{l}\text { Bupati dinilai memberikan data } \\
\text { mentah terkait dana gempa, } \\
\text { sehingga merika tidak puas dan } \\
\text { merasa kecewa }\end{array}$ \\
\hline
\end{tabular}

\footnotetext{
${ }^{22}$ Tanjung TV, Edisi 1 September 2018 "PEMDA Dinilai Lamban Menangani Korban Gempa"
} 


\begin{tabular}{|l|l|l|l|}
\hline 6 & 4 Oktober 2018 & $\begin{array}{l}\text { Dasar Teriakan Korban Gempa } \\
\text { Terkait Transparansi Bantuan }\end{array}$ & $\begin{array}{l}\text { Bupati dinilai tidak tranparan } \\
\text { terkait dana gempa, sehinga } \\
\text { merika tidak puas dan merasa } \\
\text { kecewa, padahal donator banyak }\end{array}$ \\
\hline 7 & 6 Nopember 2018 & $\begin{array}{l}\text { Polemik Pembelian Mobil Mewah } \\
\text { Wabup alasan Siva dan Teknis }\end{array}$ & $\begin{array}{l}\text { Masyarakat Merasa Bingung } \\
\text { dengan sikap Pemda KLU yang } \\
\text { membeli mobil Fortuner untuk } \\
\text { Wabup, padahal masyarakat } \\
\text { sedang susah hisup karena } \\
\text { gempa }\end{array}$ \\
& & & \\
\hline
\end{tabular}

\section{B. Analisis Isi Berita Kritik Sosial dalam Tanjung TV dengan Model Teun A. Van Dijk}

Menurut Van Dijk, penelitian analisis wacana tidak cukup hanya didasarkan pada analisis teks semata, karena teks hanya hasil dari suatu praktik produksi yang harus juga diamati.23 Pemahaman produksi teks pada akhirnya akan memperoleh pengetahuan mengapa teks bisa demikian.Wacana digambarkan oleh Van Dijk mempunyai tiga dimensi/bangunan yaitu teks, kognisi sosial, dan konteks sosial. Inti analisis model van Dijk adalah menggabungkan tiga dimensi wacana tersebut dalam satu kesatuan analisis.

1) Teks yang diteliti adalah bagaimana struktur teks dan strategi wacana yang dipakai untuk menegaskan suatu tema tertentu.

2) Pada level kognisi sosial dipelajari proses produksi teks berita yang melibatkan kognisi individu dari wartawan.

3) Sedangkan aspek konteks mempelajari bangunan wacana yang berkembang dalam masyarakat akan suatu masalah. Analisis van Dijk menghubungkan analisis tekstual ke arah analisis yang komprehensif bagaimana teks diproduksi, baik dalam hubungannya dengan individu wartawan dan masyarakat.

4) Van Dijk melihat suatu teks terdiri atas beberapa struktur/ tingkatan yang masing-masing bagian saling mendukung. Ia membaginya ke dalam tiga tingkatan. 24

5) Pertama, struktur mikro. Ini merupaan makna global dari suatu teks/umum dari suatu teks yang dapat diamati dengan melihat topik atau tema yang dikedepankan dalam suatu berita.

6) Kedua, superstruktur, ini merupakan struktur wacana yang berhubungan dengan kerangka suatu teks, bagaimana bagian-bagian teks tersusun ke dalam berita secara utuh.

7) Ketiga struktur makro adalah makna wacana yang dapat diamati dari bagian kecil dari suatu teks yakni kalimat proposisi, anak kalimat, para prase, gambar dan sebagainya.

Kalau digambarkan maka struktur teks adalah sebagai berikut: ${ }^{25}$

\begin{tabular}{|c|}
\hline $\begin{array}{c}\text { Struktur Makro } \\
\text { Makna global dari suatu teks yang dapat diamati } \\
\text { Dari topic/tema yang diangkat oleh suatu teks }\end{array}$ \\
\hline $\begin{array}{c}\text { Superstruktur } \\
\text { Kerangka suatu teks, seperti bagian pendahuluan, } \\
\text { Isi, penutup, dan kesimpulan }\end{array}$ \\
\hline \hline
\end{tabular}

\footnotetext{
${ }^{23}$ Van Dijk dalam Eriyanto. Analisis Wacana... h. 221

${ }^{24}$ Ibid., h. 226.

${ }^{25}$ Ibid., h. 227.
} 


\section{Struktur Mikro \\ Makna lokal dari suatu teks yang dapat diamati \\ Dari pilihan kata, kalimat dan gaya yang dipakai oleh suatu teks}

Pemakaian kata, kalimat, proposisi, retorika tertentu oleh media dipahami van Dijk sebagai bagian dari strategi wartawan. Pemakaian kata-kata tertentu, kalimat, gaya tertentu bukan sematamata dipandang sebagai cara berkomunikasi, tetapi dipandang sebagai politik berkomunikasisuatu cara untuk mempengaruhi pendapat umum, menciptakan dukungan, memperkuat legitimasi, dan menyingkirkan lawan atau penentang. Struktur wacana adalah cara yang efektif untuk melihat proses retorika dan persuasi yang dijalankan ketika seseorang menyampaikan pesan. Kata-kata tertentu mungkin dipilih untuk mempertegas pilihan dan sikap, membentuk kesadaran politik, dan sebagainya. ${ }^{26}$

Berikut akan diuraikan satu persatu elemen wacanaa van Dijk tersebut:

\begin{tabular}{|c|c|c|}
\hline $\begin{array}{l}\text { STRUKTUR } \\
\text { WACANA }\end{array}$ & HAL YANG DIAMATI & ELEMEN \\
\hline Struktur Makro & $\begin{array}{l}\text { Tematik } \\
\text { Tema/Topik yang dikedepankan dalam suatu berita }\end{array}$ & Topik \\
\hline Superstruktur & $\begin{array}{l}\text { Skematik } \\
\text { Bagaimana bagian dan urutan berita diskemakan } \\
\text { dalam teks utuh }\end{array}$ & Skema \\
\hline Struktur Mikro & $\begin{array}{l}\text { Semantik } \\
\text { Makna yang ingin ditekankan dalam teks berita, misal } \\
\text { dengan memberi detil pada satu sisi atau membuat } \\
\text { eksplisit satu sisi dan mengurangi detil sisi lain. } \\
\text { Sintaksis } \\
\text { Bagaimana kalimat (bentuk, susunan) yang dipilih. } \\
\text { Stilistik } \\
\text { Bagaimana pilihan kata yang dipakai dalam teks } \\
\text { berita. } \\
\text { Retoris } \\
\text { Bagaimana dan dengan cara penekanan dilakukan. }\end{array}$ & $\begin{array}{l}\text { Latar, detil, } \\
\text { maksud, pra- } \\
\text { anggapan, } \\
\text { nominalisasi } \\
\text { Bentuk kalimat, } \\
\text { Koherensi, Kata } \\
\text { ganti. } \\
\text { Leksikon } \\
\text { Grafis, Metafora, } \\
\text { Ekspresi. }\end{array}$ \\
\hline
\end{tabular}

Dalam pandangan Van Dijk, segala teks bisa dianalisis dengan menggunakan elemen tersebut. Meski terdiri atas berbagai elemen, semua elemen tersebut merupakan suatu kesatuan, saling berhubungan dan mendukung satu sama lainnya.

Karena penelitian ini hanya ingin meneliti tentang bagaimana kritik sosial dimuat dalam isi berita buletin Tanjung TV dari beberapa edisi yang ada, terutama dalam fungsi sebagai media yang menjalankan kontrol sosial, maka peneliti hanya akan menggunakan dimensi teks saja dalam analisis wacana model Van Dijk ini, dengan lebih menitik beratkan pada analisis teks Superstruktural yang bersifat skemantik, guna memudahkan peneliti dalam mengungkap 
bagaimana kritik sosial di muat, dengan cara meneliti kerangka suatu teks, seperti bagian pendahuluan, isi, penutup, dan kesimpulan dari teks berita. ${ }^{27}$

\section{1) Skemantik}

Teks atau wacana menurut Van Dijk umumnya mempunyai skema atau alur dari pendahuluan sampai akhir. Alur tersebut menunjukkan bagaimana bagian-bagian dalam teks disusun dan diurutkan sehingga membentuk kesatuan arti. Ada dua kategori skema besar dalam kategori Van Dijk dalam berita

\section{2) Summary (ringkasan)}

Ditandai dengan dua elemen. Yakni judul dan lead. ${ }^{28}$ Elemen skema ini merupakan elemen yang dipandang paling penting. Judul dan lead umumnya menunjukkan tema apa yang ingin disampaikan oleh wartawan dalam pemberitaanya. Lead biasanya merupakan pengantar ringkasan apa yang ingin dikatakan sebelum masuk dalam isi berita secara lengkap. ${ }^{29}$ Dari beberapa berita yang mengandung muatan kritis dalam Tanjung TV, skema summary ini, dapat dijumpai pada beberapa judul dan lead dari edisi terbitan, diantaranya sebagai berikut:

\begin{tabular}{|c|c|c|c|}
\hline No & Edisi & Judul & Lead \\
\hline 1 & 6 September 2018 & $\begin{array}{l}\text { Banyakan Rapat } \\
\text { Pemda KLU dinilai } \\
\text { Lamban Menangani } \\
\text { Korban Gempa }\end{array}$ & $\begin{array}{l}\text { Akibat gempa yang melanda Kabupaten } \\
\text { Lombok Utara } 1 \text { bulan terakhir membuat } \\
\text { berbagai persoalan baru baik di sektor } \\
\text { pemerintahan dan berbagai pelayanan publik } \\
\text { lainnya lebih dari sebulan lamanya pemerintah } \\
\text { bergelut mulai dengan problematika sosial yang } \\
\text { timbul akibat bencana ini sehingga peran } \\
\text { pemerintah kurang terlihat hingga menjadi } \\
\text { sorotan dari berbagai kalangan }\end{array}$ \\
\hline 2 & 1 September 2018 & $\begin{array}{lr}\text { Korban } & \text { Gempa } \\
\text { Butuh Pekerjaan dan } \\
\text { Kepastian Jaminan } \\
\text { Hidup }\end{array}$ & $\begin{array}{l}\text { Warga korban gempa saat ini sudah mulai } \\
\text { kembali ke rumah-rumah mereka setelah hampir } \\
1 \text { bulan mereka meninggalkan rumah dan hidup } \\
\text { di pengungsian setelah mereka sampai ke rumah } \\
\text { mereka pun mulai berbenah bedah } \\
\text { membersihkan puing-puing rumah mereka yang } \\
\text { sudah ambruk tertimpa gempa banyak dari } \\
\text { mereka yang merobohkan sendiri rumah-rumah } \\
\text { mereka untuk menyelamatkan beberapa bahan } \\
\text { bangunan rumah yang masih bisa dimanfaatkan } \\
\text { untuk dipakai membuat rumah yang baru } \\
\text { Namun dibalik itu semua saat ini bahan } \\
\text { persediaan makanan sudah sangat menipis } \\
\text { sehingga peran pemerintah sangat dibutuhkan } \\
\text { untuk mengurangi beban hidup mereka setelah } \\
\text { kembali dari pengungsian }\end{array}$ \\
\hline 3 & 27 September 2019 & $\begin{array}{l}\text { Kantor Bupati KLU } \\
\text { Di Demo Terkait } \\
\text { Dengan Pencairan } \\
\text { dana }\end{array}$ & $\begin{array}{l}\text { Ratusan warga yang menjadi korban gempa di } \\
\text { Kabupaten Lombok Utara melakukan aksi demo } \\
\text { di Kantor bupati Lombok Utara. } \\
\text { Play Box Roll... } \\
\text { Aksi tersebut didasarkan atas kebingungan } \\
\text { warga terkait dengan kebijakan bantuan yang } \\
\text { akan diberikan kepada warga yang jadi korban } \\
\text { gempa terkait dengan bantuan rumah dan }\end{array}$ \\
\hline
\end{tabular}

\footnotetext{
${ }^{27}$ Ibid... h. 227

${ }^{28}$ Teras berita, disebut pula lead, adalah bagian berita yang terletak di alenia atau paragraf pertama. Ters berita merupakan bagian dari komposisi atau susunan berita, yakni setelah judul berita (head) dan sebelum badan berita (news body). Lihat Asep Syamsul M. Romli, Jurnalistik Praktis Untuk Pemula, (Bandung: PT Remaja Rosdakarya, 2006), h. 13.

${ }^{29}$ Superstruktur skematik, adalah bagaimana bagian dan urutan berita dikemas dalam teks berita utuh.
} 


\begin{tabular}{|c|c|c|c|}
\hline & & & jaminan hidup \\
\hline 4 & 4 Oktober 2018 & $\begin{array}{lr}\text { Dasar } & \text { Teriakan } \\
\text { Korban } & \text { Gempa } \\
\text { Terkait Transparansi } \\
\text { Bantuan }\end{array}$ & $\begin{array}{l}\text { Kekecewaan warga korban gempa terhadap } \\
\text { data-data donatur yang diterima dari pemerintah } \\
\text { Kabupaten Lombok Utara cukup berdasar } \\
\text { karena dengan banyaknya donatur yang datang } \\
\text { membantu sampai saat ini masih banyak yang } \\
\text { belum dirasakan oleh warga }\end{array}$ \\
\hline 5 & & $\begin{array}{lr}\text { Suara } & \text { Nelayan } \\
\text { Lombok } & \text { Utara Pasca } \\
\text { Gempa } & \text { Tentang } \\
\text { Keluhan } & \text { Mereka } \\
\text { Saat Ini } & \\
\end{array}$ & $\begin{array}{l}\text { Nelayan di Kabupaten Lombok Utara saat ini } \\
\text { sedang membutuhkan uluran tangan dari } \\
\text { pemerintah setempat karena gempa yang } \\
\text { melanda Kabupaten Lombok Utara. }\end{array}$ \\
\hline
\end{tabular}

Dalam judul dan lead di atas, jika diperhatikkan terdapat sebuah skema/alur yang membentuk suatu keasatuan utuh, dimana antara judul dan lead yang ada saling berhubungan dan mendukung satu sama lain. Dan secara keseluruhan, judul-judul diatas adalah salah satu bentuk kontrol (kritik) sosial yang secara umum lebih ditujukan oleh media Tanjung TV kepada pemerintah terkait kebijakan-kebijakan pasca gempa 2018. Ini bisa dilihat dari judul-judul yang kritis yang kemudin didukung oleh lead yang kritis pula, baik itu dengan menyertakan komentar atau fakta-fakta lain dalam berita yang mendukung pesan kritis pada judul-judul yang diangkat.

\section{1) Story}

Kategori skema besar yang kedua menurut Van Dijk adalah story, yakni elemen yang menilai isi berita secara keseluruhan. Skema story juga mempunyai dua subkategori,

a) Berupa situsi, yakni jalannya proses atau jalannya peristiwa di dalam berita.

b) Komentar yang ditampilkan oleh wartawan di dalam teks.

Misalnya dalam berita yang dimuat pada edisi 6 September 2018 dengan judul "Banyakan Rapat Pemda KLU dinilai Lamban Menangani Korban Gempa" Dimana pendahuluan, isi, penutup dan kesimpulan secara keseluruhan digambarkan dengan utuh mulai dari situasi, proses jalannya peristiwa, dan komentar-komentar yang disertakan sebagai berikut:

\section{a) Pendahuluan}

Pada bagaian pendahuluan edisi ini, dijelaskan dalam bagian pertama sebagai berikut:

Akibat gempa yang melanda Kabupaten Lombok Utara 1 bulan terakhir membuat berbagai persoalan baru baik di sektor pemerintahan dan berbagai pelayanan publik lainnya lebih dari sebulan lamanya pemerintah bergelutmulai dengan problematika sosial yang timbul akibat bencana ini sehinggaperan pemerintah kurang terlihat hingga menjadi sorotan dari berbagai kalangan.

Jasman hadi Salah satu tokoh masyarakat Pemenang, melihat pemerintah daerah masih kurang tanggap terhadap persoalan pendidikan karena sampai saat ini masih banyak sekolah yang masih belum memiliki tenda untuk tempat berteduh belajar. Terlebih mereka, banyak yang akan menempuh ujian sekolah sehingga mereka sangat perlu untuk dibuatkan sekedar Anda guna belajar sementara. Jasman Hadi juga melihat pembahasan APBD perubahan Sudah saatnya segera disesuaikan dengan anggaran yang dianggap paling urgent, karena tidak mungkin Lombok Utara akan berpangku tangan menghadapi persoalan masyarakat dengan mengandalkan bantuan dari luar saja 
b) Isi

Selanjutnya pada bagian isi berita dapat ditemukan beberapa komentar yang menjelaskan tentang:

- Pemerintah Lamban menangani persoalan pedndidikan

- Pemerintah tidak bisa mengambil tindakan di saat genting

- Pemerintah Lamban dalam Pelayanan Publik, dll

- Pada bagian isi berita juga ditampilkan komentar yang sama dari Jasman Hadi yang mengatakan, pemerintah lamban dalam mengambil kebijakan, karena energy mereka habis untuk rapat, tapi tidak ada aksi di lapangan. Seperti yang dikatakan Jasman Hadi sebagai berikut:

- Energi itu banyak dikuras hanya untuk rapat2, mengadu argumentasi, tetapi tidak ada tindakan nyata.

c) Penutup

Pada akhir dari berita ini wartwan Tanjung TV menutup dengan pandangan Jasman Hadi yang merupakan mantan Ketua Komisi I DPRD KLU agar pemerintah lebih tanggap terhadap permasalahan karena kalau di saat Genting keputusan tidak harus diputuskan di ruang ber-ac, tapi di lapangan juga.

d) Kesimpulan

Pada berita edisi ini, diambil kesimpulan bahwa kritik yang ingin disampaikan adalah lambannya pemerintah mengambil keputusan disaat genting, padahal masyarakat sedang membutuhkan kebijakan-kebijakan yang bisa membuat mereka tenang di tengah musibah gempa yang menimpa mereka.

Dalam berita yang dimuat pada edisi 29 November 2018 dengan judul "Suara Nelayan Lombok Utara pasca Gempa Tentnag Keluhan Mereka Saat ini" Dimana pendahuluan, isi, penutup dan kesimpulan secara keseluruhan digambarkan dengan utuh mulai dari situasi, proses jalannya peristiwa, dan komentar-komentar yang disertakan sebagai berikut:

a) Pendahuluan

Pada bagaian pendahuluan edisi ini, dijelaskan dalam bagian pertama sebagai berikut:

Nelayan di Kabupaten Lombok Utara saat ini sedang membutuhkan uluran tangan dari pemerintah setempat karena gempa yang melanda Kabupaten Lombok Utara.

Belum lama ini banyak peralatan nelayan yang rusak akibat gempa hal itu dikatakan oleh Budiana salah satu nelayan di Dusun penyembuhan Desa Jenggala Kabupaten Lombok Utara. Saat ini, nelayan menginginkan dari pemerintah agar diberikan mesin tempel kepada kelompokkelompok yang ada di Lombok Utara untuk meningkatkan produksi mereka karena dengan menggunakan mesin tempel tersebut mereka bisa menggunakan untuk menangkap ikan ke tempat yang lebih jauh dan hasilnya juga bisa lebih banyak.

b) Isi

Selanjutnya pada bagian isi berita dapat ditemukan beberapa komentar yang menjelaskan tentang:

- Harapan nelayan agar pemerintah peka terhadap kebutuhan mereka pasca gempa

- Program pemerintah yang pro nelayan

c) Penutup

Pada akhir dari berita ini wartwan Tanjung TV menutup dengan pandangan bahwa Jadi suara arus bawah yang harus didengarkan dan seharusnya mendapatkan perhatian dari pemerintah daerah setempat. 
d) Kesimpulan

Pada berita edisi ini, diambil kesimpulan bahwa kritik yang ingin disampaikan adalah program pemerintah yang pro nelayan, apalagi pasca gempa yang telah banyak merenggut harta benda mereka.

\section{Kesimpulan}

Temuan penelitian ini menunjukkan bahwasanya:

Tanjung TV dalam pemberitaannya dari kurun waktu bulan Agustus-Desember banyak memuat berita yang mengandung muatan kritik sosial, terutama kritik terkait Kebijakan Pemda KLU dalam menangani korban Gempa 2018. Kritik yang ditujukan beragam, ada kritik terkait pendidikan, kesehatan, tranparansi bantuan sembako, kejelasan bantuan hunian, tranparansi aliran dana dari donator, pelayanan public, serta lambannya pemerintah dalam mengambil tindakan.

Kritik sosial dimuat, dikemas serta didukung oleh data-data yang memperkuat kritik yang ingin disampaikan. Baik itu dengan cara menyertakan komentar-komentar dari narasumbernarasumber yang mendukung kritik pada topik tertentu, atau dengan menyertakan data-data tertentu, sehingga apa yang dipaparkan dalam berita, adalah benar-benar terjadi dan merugikan khalayak.

Selain itu, untuk mendukung kritik-kritik pada topik tertentu yang ingin disampaikan dalam beberapa berita Tanjung TV, wartawan menyusun bagian-bagian berita dengan urutan tertentu. Ada tekanan mana yang didahulukan, dan bagian mana yang dibuang, sebagai strategi untuk menyembunyikan informasi penting

\section{DAFTAR PUSTAKA}

Alo Liliweri, 2011. Komunikasi: Serba Ada Serba Makna. Jakarta: Kencana.

Anselm Straus \& Juliet Corbin, 2013. Dasar-dasar Penelitian Kualitatif. Yogyakarta: Pustaka Pelajar

Asep Syamsul M. Romli, 2006. Jurnalistik Praktis Untuk Pemula, Bandung: PT Remaja Rosdakarya.

Deddy Iskandar Muda, 2005. Jurnalistik Televisi Menjadi Reporter Profesional, Bandung: Remaja Rosda Karya.

Deddy Mulyana (Ed), 2011. Ilmu Komunikasi Sekarang dan Tantangan Masa Depan. Jakarta: Kencana.

Eriyanto, 2009. Analisis Wacana; Pengantar Analisis Teks Media, Yogyakarta; LkiS

Hikmat K. dan Purnama K., 2009. Jurnalistik Teori \& Praktik, (Ed), Bandung: PT Remaja Rosdakarya

Idi Subandi Ibrahim, 2011. Kritik Budaya Komunikasi. Yogyakarta: Jalasutra

Mc Quail dalam Henri Subiakto, 2012. Komunikasi Politik, Media dan Demokrasi, (Jakarta: Prenada Media Group.

Mursito, 2012. Realitas Media. Surakarta: Smart Media

Septiawan Santana K., 2005. Jurnalisme Kontemporer, Jakarta; Yayasan Obor Indonesia.

Tanjung TV, Edisi 1 September 2018 "PEMDA Dinilai Lamban Menangani Korban Gempa"

William L. Rivers, 2008. Media Massa \& Masyarakat, Jakarta: Kencana. 